Огляди літератури, оригінальні дослідження, погляд на проблему, випадок з практики, короткі повідомлення удК 616.36-003.826:616-056.257-02:616.721.1-007.24

DOI 10.11603/1811-2471.2020.v.i4.11767

\title{
ВПЛИВ ПОРУШЕННЯ МАСИ ТІЛА НА ВИРАЖЕНІСТЬ ПРОЯВІВ ОТЕОХОНДРОЗУ У ХВОРИХ НА НЕАЛКОГОЛЬНУ ЖИРОВУ ХВОРОБУ ПЕЧІНКИ
}

\author{
๑я. Ф. Філак, Є. С. Сірчак \\ ДВНЗ «Ужгородський національний університет»
}

РЕЗЮМЕ. Остеохондроз (ОХ) хребта - одна з найпоширеніших хвороб дорослого населення. Серед основних причин розвитку остеохондрозу лікарі виділяють порушення обміну речовин, низький фізичний розвиток, генетичну схильність, ожиріння, куріння.

Мета - вивчити клінічні особливості перебігу ОХ поперекового відділу хребта (ПВХ) у хворих на неалкогольну жирову хворобу печінки (НАЖХП) залежно від вираженості порушення індексу маси тіла (IMT) у пацієнтів.

Матеріал і методи. Під нашим спостереженням перебували 42 хворих на НАЖХП та ОХ ВПХ. Усім обстеженим пацієнтам проведено загальноклінічні, антропометричні, інструментальні та лабораторні дослідження. Для дослідження рухової здатності хребта проводили функціональну оцінку рухливості хребта й м'язової сили спини та черевного преса.

Результати. У переважної більшості обстежених нами пацієнтів з НАЖХП та ОХ ПВХ при аналізі результатів антропометричного дослідження виявлена надмірна вага тіла або ожиріння різного ступеня вираженості. У хворих на НАЖХП та ОХ ПВХ частіше діагностовано надмірну вагу тіла (42,9 \%) та ожиріння I ст. (28,6 \%) і лише у 9,5 \% обстежених встановлено нормальну вагу тіла. Отримані результати дослідження вказують на значне погіршення рухливості хребта в поперековому відділі у хворих на НАЖХП та ОХ ПВХ. Встановлена закономірність прогресування показників рухової активності залежно від вираженості порушення ІМТ. Максимальні рухові порушення визначено у пацієнтів з ожирінням II ст. за результатами тесту Шобера, тесту «пальці - підлога» та розгинання $((2,00 \pm 0,18)$ см - p<0,01; $(16,71 \pm 0,32)$ см - p<0,01; $(7,12 \pm 0,13)$ см - p<0,05 відповідно). Ці зміни мають стадійний характер, з мінімальними показниками у пацієнтів з нормальною вагою тіла і з максимальними при ожирінні ІІ ст.

Висновки. У хворих на НАЖХП та ОХ ПВХ із збільшення ІМТ виявлено прогресування порушень рухової активності поперекового відділу хребта. У хворих на НАЖХП та ОХ ПВХ ожиріння різного ступеня вираженості та надмірну вагу тіла частіше виявляли в осіб без освіти або з середньою спеціальною освітою.

КЛючОВІ СлОВА: неалкогольна жирова хвороба печінки; остеохондроз; ожиріння.

Вступ. Сьогодні серцево-судинні захворювання, цукровий діабет 2-го типу, ожиріння, неалкогольна жирова хвороба печінки (НАЖХП), метаболічний синдром тощо вважають всесвітньою епідемією неінфекційних хвороб. Сучасний пацієнт - це хворий з коморбідним, поліморбідним фоном.

Неалкогольна жирова хвороба печінки обіймає провідну позицію серед хронічних захворювань печінки й складає 71,6 \% від загальної їх кількості [1]. Патологія охоплює 17-46 \% дорослого населення з відмінностями залежно від методу діагностики, віку, статі та етнічної належності [2], а також - до 70 \% пацієнтів із діабетом та ожирінням [3]. Деякі автори пропонують вважати НАЖХП однією із складових метаболічного синдрому [1], розглядаючи ії як печінковий прояв МС $[2,3]$. На сьогодні доведено спільність патогенетичних механізмів для НАЖХП та метаболічного синдрому і стає очевидним їх зв'язок із цукровим діабетом 2-го типу, серцево-судинними захворюваннями і тяжкими формами захворювання печінки, включно з цирозом і гепатоцелюлярною карциномою. Отже, НАЖХП охоплює спектр захворювань, тісно пов'язаних із метаболічними факторами ризику [3-5].

Остеохондроз (ОХ) хребта - також одна з найпоширеніших хвороб серед дорослого населен- ня, на яку страждає від 40 до 80 \% жителів земної кулі. Проявами остеохондрозу $\epsilon$ біль у спині, головний біль, на що скаржиться кожна 3-4 людина віком понад 30 років. Серед основних причин розвитку остеохондрозу лікарі виділяють порушення обміну речовин, низький фізичний розвиток, генетичну схильність, ожиріння, куріння $[6,7]$. Отже, порушення обмінних процесів, наявні у хворих із метаболічно асоційованими захворюваннями (НАЖХП, цукровий діабет 2-го типу, ожиріння) можуть бути однією з причин формування ураження хребта, а також можуть мати обтяжливий вплив на його прогресування при ОХ. Становить певний інтерес визначення факторів, що впливають на прогресування ураження хребта при НАЖХП, особливо у хворих із ожирінням.

Мета - вивчити клінічні особливості перебігу OX поперекового відділу хребта (ПВХ) у хворих на НАЖХП залежно від вираженості порушення індексу маси тіла (IMT) у цих пацієнтів.

Матеріал і методи дослідження. Під нашим спостереженням перебували 42 хворих на НАЖХП та OX ВПХ, які отримували стаціонарне лікування В ендокринологічному, гастроентерологічному, неврологічному відділеннях КНП «ЗОКЛ імені А. Новака» ЗОД, та хворі, які перебували на амбулаторнодиспансерному спостереженні у дільничного сі- 
Огляди літератури, оригінальні дослідження, погляд на проблему, випадок з практики, короткі повідомлення мейного лікаря за місцем проживання. Серед обстежених хворих на НАЖХП було 24 чоловіки (57,1 \%) та 18 жінок (42,9\%). Середній вік обстежених становив $(47,8 \pm 5,3)$ років.

У контрольну групу ввійшли 20 практично здорових осіб (чоловіків було 13 (65,0\%), жінок 7 (35,0 \%) без проявів ураження печінки та патології опорно-рухового апарату. Середній їх вік складав $(46,3 \pm 4,2)$ років.

Усі дослідження виконували за згодою паці$\epsilon$ тів, а методика їх проведення відповідала Гельсінській декларації з прав людини 1975 р. та її перегляду 1983 р., Конвенції Ради Європи про права людини і біомедицину та законодавству України.

Діагноз НАЖХП встановлювали згідно з критеріями уніфікованого клінічного протоколу (наказ МОз України від 06.11.2014 р. № 826) та клінічними рекомендаціями EASL-EASD-EASO щодо діагностики та лікування НАЖХП [8].

При антропометричному дослідженні визначали зріст, вагу, обвід талії, а також розраховували індекс маси тіла (IMT). Згідно з рекомендаціями ВООЗ, хворих поділили залежно від показника IMT, при якому IMT 16,0 і менше відповідав вираженому дефіциту маси тіла; 16,0-18,5 - недостатній масі тіла; 18,0-24,9 - нормальній масі; 25,029,9 - надмірній масі; 30,0-34,9- ожирінню I ступеня; 35,0-39,9 - ожирінню II ступеня; 40,0 і більше ожирінню III ступеня (морбідне ожиріння) [9].

Остеохондроз поперекового відділу хребта діагностували на основі фізикальних, загальноклінічних методів обстеження, а також результатів комп'ютерної томографії поперекового відділу хребта. Для дослідження рухової здатності хребта проводили функціональну оцінку рухливості хребта й м'язової сили спини та черевного преса (тест Шобера, розгинання хребта, тест «пальці - підлога», функціональні проби для визначення силової витривалості м'язів-розгиначів спини та черевного преса) [10].

Аналіз і обробку результатів обстеження хворих здійснювали за допомогою комп'ютерної програми Statistics for Windows v.10.0 (StatSoft Inc, USA) з використанням параметричних та непараметричних методів оцінки отриманих результатів.

Результати й обговорення. У переважної більшості обстежених нами хворих на НАЖХП та OX ПВХ при аналізі результатів антропометричного дослідження виявлена надмірна вага тіла або ожиріння різного ступеня вираженості, що проявлялось збільшенням IMT, а також індексу талія/стегно (ITC) - табл. 1.

Таблиця 1. Показники антропометричного дослідження у обстежених

\begin{tabular}{|l|c|c|}
\hline \multicolumn{1}{|c|}{ Показник } & $\begin{array}{c}\text { Контрольна група } \\
(n=20)\end{array}$ & $\begin{array}{c}\text { Обстежені хворі на НАЖХП та ОХ ПВХ } \\
(n=42)\end{array}$ \\
\hline IMT, кг/M ${ }^{2}$ & $23,4 \pm 0,81$ & $36,30 \pm 1,28^{*}$ \\
\hline ITC, ум.од. & $0,79 \pm 0,32$ & $1,39 \pm 0,43^{*}$ \\
\hline
\end{tabular}

Примітка. Різниця між показниками хворих та обстежених осіб контрольної групи достовірна: * - p<0,05.

У всіх обстежених контрольної групи встановлена нормальна вага тіла за показником IMT $(23,4 \pm 0,81) \mathrm{kr} / \mathrm{M}^{2}$.

У хворих на НАЖХП та ОХ ПВХ частіше діагностували надмірну вагу тіла (42,9\%) та ожиріння I ст. (28,6 \%), і лише у 9,5\% обстежених була нормальна вага тіла. Результати наведені у таблиці 2.

У обстежених хворих на НАЖХП та ОХ ПВХ визначено функціональну спроможність хребта в сагітальній та фронтальній площинах залежно від вираженості порушення IMT (табл. 3, 4).

Таблиця 2. Розподіл обстежених хворих на неалкогольну жирову хворобу печінки та остеохондроз поперекового відділу хребта залежно від індексу маси тіла

\begin{tabular}{|l|c|}
\hline \multicolumn{1}{|c|}{ Показник } & $\begin{array}{c}\text { Обстежені хворі на НАжХП та ОХ ПВХ } \\
\text { (n=42) }\end{array}$ \\
\hline $\begin{array}{l}\text { Нормальна вага } \\
\text { (IМТ: } 18,0-24,9)\end{array}$ & $9,5 \%$ \\
\hline $\begin{array}{l}\text { Надмірна вага } \\
\text { (IМТ: } 25,0-29,9)\end{array}$ & $42,9 \%$ \\
\hline $\begin{array}{l}\text { Ожиріння І ступеня } \\
\text { (ІМТ: } 30,0-34,9)\end{array}$ & $28,6 \%$ \\
\hline $\begin{array}{l}\text { Ожиріння ІІ ступеня } \\
\text { (ІМТ: } 35,0-39,9)\end{array}$ & $19,0 \%$ \\
\hline
\end{tabular}

Примітка. Різниця між показниками у хворих I та II груп достовірна: * - p<0,05. 
Огляди літератури, оригінальні дослідження, погляд на проблему, випадок з практики, короткі повідомлення Таблиця 3. Дослідження рухливості поперекового відділу хребта в сагітальній площині

\begin{tabular}{|c|c|c|c|c|c|}
\hline \multirow{3}{*}{ Показник } & \multicolumn{5}{|c|}{ Обстежені } \\
\hline & \multirow{2}{*}{$\begin{array}{c}\text { контрольна } \\
\text { група } \\
(n=20)\end{array}$} & \multicolumn{4}{|c|}{ хворі на НАЖХП та ОХ ПВХ $(n=42)$} \\
\hline & & нормальна вага & надмірна вага & ожиріння I ст. & $\begin{array}{l}\text { ожиріння } \\
\text { ІІ ст. }\end{array}$ \\
\hline $\begin{array}{l}\text { Згинання } \\
\text { (тест Шобера), см }\end{array}$ & $3,82 \pm 0,11$ & $3,05 \pm 0,11$ & $2,95 \pm 0,23 *$ & $2,34 \pm 0,09 * *$ & $2,00 \pm 0,18^{* *},+$ \\
\hline $\begin{array}{l}\text { Нахил уперед (тест } \\
\text { «пальці - підлога»), см }\end{array}$ & $31,63 \pm 0,47$ & $27,33 \pm 0,15^{*}$ & $23,17 \pm 0,50 *$ & $18,22 \pm 0,12^{* *},+$ & $16,71 \pm 0,32 * *,++$ \\
\hline Розгинання, см & $11,95 \pm 0,18$ & $10,03 \pm 0,20$ & $9,04 \pm 0,12 *$ & $7,88 \pm 0,26^{*}$ & $7,12 \pm 0,13 *,+$ \\
\hline
\end{tabular}

Примітка. Різниця між показниками у хворих та обстежених осі6 контрольної групи достовірна: * $-p<0,05 ;$ ** $-p<0,01 ;$ різниця між показниками у хворих на НАЖХП та ОХ ПВХ з нормальною вагою тіла та порушенням IMТ достовірна +-p<0,05; ++ - p<0,01.

Таблиця 4. Дослідження рухливості поперекового відділу хребта у фронтальній площині

\begin{tabular}{|c|c|c|c|c|c|}
\hline \multirow{3}{*}{ Показник } & \multicolumn{5}{|c|}{ Обстежені } \\
\hline & \multirow{2}{*}{$\begin{array}{c}\text { контрольна } \\
\text { група } \\
(n=20)\end{array}$} & \multicolumn{4}{|c|}{ хворі на НАЖХП та ОХ ПВХ (n=42) } \\
\hline & & нормальна вага & надмірна вага & ожиріння I ст. & $\begin{array}{c}\text { ожиріння } \\
\text { II ст. }\end{array}$ \\
\hline Нахил вліво, см & $54,21 \pm 0,28$ & $49,14 \pm 0,31$ & $48,23 \pm 0,41 *$ & $48,09 \pm 0,23 *$ & $47,12 \pm 0,17 *$ \\
\hline Нахил вліво, см & $58,26 \pm 0,44$ & $53,71 \pm 0,39$ & $53,29 \pm 0,41$ & $50,25 \pm 0,22 *$ & $49,11 \pm 0,25 * *,+$ \\
\hline $\begin{array}{l}\text { Силова витривалість, с } \\
\text { м'язів спини } \\
\text { м'язів черевного преса }\end{array}$ & $\begin{array}{l}22,80 \pm 0,29 \\
25,13 \pm 0,14\end{array}$ & $\begin{array}{l}19,88 \pm 0,20 \\
21,25 \pm 0,19\end{array}$ & $\begin{array}{l}19,23 \pm 0,25 \\
20,14 \pm 0,45\end{array}$ & $\begin{array}{l}17,45 \pm 0,31 * \\
18,47 \pm 0,11^{*}\end{array}$ & $\begin{array}{c}17,14 \pm 0,20^{*} \\
18,22 \pm 0,17^{*},+\end{array}$ \\
\hline
\end{tabular}

Примітка. Різниця між показниками у хворих та обстежених осіб контрольної групи достовірна: * - p<0,05; різниця між показниками у хворих на НАЖХП та ОХ ПВХ з нормальною вагою тіла та порушенням IMТ достовірна + - p<0,05.

Отримані результати дослідження вказують на значне погіршення рухливості (гнучкості) хре6та в поперековому відділі при його згинанні, розгинанні й нахилах вправо та вліво у хворих на НАЖХП та ОХПВХ. При цьому встановлена закономірність прогресування показників рухової активності залежно від вираженості порушення IMT. Максимальні рухові порушення визначено у пацієнтів з ожирінням II ст. за результатами тесту Шобера, тесту «пальці - підлога» та розгинання $(2,00 \pm$ $0,18 \mathrm{~cm}-\mathrm{p}<0,01 ; 16,71 \pm 0,32 \mathrm{~cm}-\mathrm{p}<0,01 ; 7,12 \pm 0,13 \mathrm{~cm}-$ p $<0,05$ відповідно). Слід зазначити, що у хворих на НАХЖП та ОХ ПВХ при нормальній вазі тіла вказані показники статистично достовірно відрізнялися від таких у хворих з ожирінням I-ІІ ступенів, а також з надмірною вагою тіла.

Проведене дослідження рухової активності поперекового відділу хребта у фронтальній площині також вказує на максимальні зміни у хворих на
НАЖХП та ОХ ПВХ з ожирінням II СТ., а мінімальні відхилення встановлено у хворих з нормально вагою тіла. Отже, зміни мають стадійний характер - 3 мінімальними показниками у пацієнтів з IMT 18,024,9 (нормальна вага) і з максимальними при IMT 35,0 - 39,9 (ожирінні II ст.). Отже, надмірна вага тіла й ожиріння мають обтяжливий вплив на стан пацієнтів з ОХ ПВХ при НАЖХП, що підтверджувалося зниженням функціональних можливостей хребетного стовпа, зменшенням силової витривалості м'язів спини та черевного преса, що вимагає проведення профілактичних заходів щодо прогресуванняураження хребтау даного контингенту пацієнтів.

Ми проаналізували порушення IMT залежно від рівня освіти у обстежених хворих (табл. 5). При цьому нормальна вага виявлена лише у хворих з вищою освітою. Надмірну вагу тіла також спостерігали частіше у обстежених пацієнтів з вищою та середньою спеціальною освітою.

Таблиця 5. Розподіл обстежених хворих на неалкогольну жирову хворобу печінки та остеохондроз поперекового відділу хребта залежно від індексу маси тіла та рівня освіти

\begin{tabular}{|l|c|c|c|}
\hline \multirow{2}{*}{ Індекс маси тіла } & \multicolumn{3}{|c|}{ Рівень освіти } \\
\cline { 2 - 4 } & без освіти & середня спеціальна & вища \\
\hline Нормальна вага & - & - & $100,0 \%$ \\
\hline Надмірна вага & $16,6 \%$ & $27,8 \%$ & $16,6 \%$ \\
\hline Ожиріння І ст. & $50,0 \%$ & $33,3 \%$ & $12,5 \%$ \\
\hline Ожиріння ІІ ст. & $50,0 \%$ & $37,5 \%$ & \\
\hline
\end{tabular}


Огляди літератури, оригінальні дослідження, погляд на проблему, випадок з практики, короткі повідомлення

Отже, у хворих на НАЖХП та ОХ ПВХ ожиріння різного ступеня вираженості частіше виявляли у пацієнтів без освіти або з середньою спеціальною освітою. Детальний аналіз анамнезу дав змогу визначити, що пацієнти з вищою освітою більш критично ставляться до стану свого здоров'я. Вони частіше займаються систематично фізичними тренуваннями з метою профілактики ожиріння, контролюють показники ліпідного та вуглеводного обмінів за допомогою спеціальних дієт, а також модифікації способу життя. Навпаки, обстежені пацієнти без вищої освіти негативно ставляться до модифікації способу життя з метою зниження IMT.

За даними результатів нашого дослідження встановлено, що ожиріння має обтяжливий вплив на клінічні прояви ОХ ПВХ у хворих на НАЖХП. Модифікація способу життя при виявленні ураження печінки, порушень метаболічних процесів в орга- нізмі, виконання систематичних фізичних тренувань для профілактики прогресування збільшення IMT та проявів OX ПВX залежать від рівня освіти пацієнтів. При цьому особливу увагу слід приділяти фізичній активності та фізичній реабілітації пацієнтів для зменшення медикаментозного навантаження на організм при НАХЖП та ОХ ПВХ.

Висновки: 1. У хворих на НАЖХП та ОХ ПВХ із збільшення IMT прогресують порушення рухової активності поперекового відділу хребта.

2. У хворих на НАЖХП та ОХ ПВХ ожиріння різного ступеня вираженості та надмірна вага тіла частіше розвиваються в осіб без освіти або із середньою спеціальною освітою.

Перспективи подальших досліджень. Подальші дослідження особливостей ураження хребта при метаболічно асоційованих захворюваннях проводитимуться з метою розробки методів їх профілактики та запобігання прогресуванню.

\section{ЛІТЕРАТУРА}

1. Ивашкин В. Т. Диагностика и лечение неалкогольной жировой болезни печени : клинические рекомендации / В. Т. Ивашкина. - М. : МЕД-пресс-информ, 2015. - 32 c.

2. Неінвазивна діагностика фіброзу печінки у хворих із неалкогольною жировою хворобою печінки / Ю. М. Степанов, Н. В. Недзвецька, В. Б. Ягмур [та ін.] // Гастроентерологія. - 2017. - Т. 51, № 3. - С. 188-195.

3. Неалкогольна жирова хвороба печінки: особливості метаболічних змін на різних етапах розвитку хвороби / Ю. М. Степанов, Н. В. Недзвецька, В. Б. Ягмур, І. А. Кленіна // Гастроентерологія. - 2018. - Т. 52, № 1. - С. 13-18.

4. Драгомирецкая Н. В. Новые возможности немедикаментозного лечения больных с неалкогольной жировой болезнью печени / Н. В. Драгомирецкая, И. Б. Заболотная, А. Н. Ижа // Гастроентерологія. - 2014. - № 2 (52). - C. 42-45.

5. Фадеенко Г. Д. Эффективность и безопасность адеметионина при коррекции функции печени у пациентов со стеатогепатитом. Результаты открытого сравнительного постмаркетингового исследования / Г. Д. Фадеенко, А. Е. Гриднев // Гастроентерологія. - 2018. - Т. 52, № 2. - C. 27-34.

\section{REFERENCES}

1. Ivaskin, V.T. (2015). Diagnostika i lecheniye nealkogolnoy zhirovoy bolezni pecheni: klinicheskiye rekomendatsii [Diagnosis and treatment of nonalcoholic fatty liver disease: clinical recommendations]. Moscow: MED-press-inform [in Russian].

2. Stepanov, Yu.M., Nedzvetskaya, N.V., Yagmur, V.B., Klenina, I.A., \& Oshmyanskaya, N. (2017). Neinvazyvna diahnostyka fibrozu pechinky u khvorykh iz nealkoholnoiu zhyrovoiu khvoroboiu pechinky [Noninvasive diagnosis of liver fibrosis

6. Epidemiology of hospitalized osteochondritis dissecans in young people: incidence, geographical variation and trends over time in England from 2002 to 2010 / O. J. Keenan, P. G. Turner, D. Yeates, M. J. Goldacre // Knee. - 2014. - No. 21 (2). - P. 497-500.

7. Мапченко О. М. Комплексная физическая реабилитация при остеохондрозе грудного отдела позвоночника с нарушением осанки / О. К. Марченко, В. Н. Манжуловский, Е. Г. Дешевый // Спортивна медицина. 2013. - № 2. - P. 123-126.

8. EASL-EASD-EASO Clinical Practice Guidelines for the management of non-alcoholic fatty liver disease / European Association for the Study of the Liver (EASL), European Association for the Study of Diabetes (EASD) and European Association for the Study of Obesity (EASO) // J. Hepatol. - 2016. - Vol. 64. - P. 1388-1402.

9. WHO: Global Database on Body Mass Index. - Access mode : http://apps.who.int/bmi/index.jsp?introPage= intro_3.html.

10. World Health Organization, Global Recommendations on Physical Activity for Health (WHO). - 2011. - Access mode : http://whqlibdoc.who.int/publications/2010/ 9789241599979_eng.pdf

in patients with nonalcoholic fatty liver disease]. Hastroenterolohiia - Gastroenterology, 51 (3), 188-195 [in Ukrainian].

3. Stepanov, Yu.M., Nedzvetskaya, N.V., Yagmur, V.B., \& Klenina, I.A. (2018). Nealkoholna zhyrova khvoroba pechinky: osoblyvosti metabolichnykh zmin na riznykh etapakh rozvytku khvoroby [Non-alcoholic fatty liver disease: features of metabolic changes at different stages of the disease]. Hastroenterolohiia - Gastroenterology, 52 (1), 1318 [in Ukrainian]. 
Огляди літератури, оригінальні дослідження, погляд на проблему, випадок з практики, короткі повідомлення

4. Dragomiretska, N.V., Zabolotna, I.B., \& Izha, G.M. (2014). Novyye vozmozhnosti nemedikamentoznogo lecheniya bolnykh s nealkogolnoy zhirovoy boleznyu pecheni [New potential of non-alcoholic fatty liver disease]. Hastroenterolohiia - Gastroenterology, 2 (52), 42-45 [in Russian].

5. Fadienko, G.D., \& Gridnyev, A.E. (2018). Effektivnost i bezopasnost ademetionina pri korrektsii funktsii pecheni u patsiyentov so steatogepatitom. Rezultaty otkrytogo sravnitelnogo postmarketingovogo issledovaniya [Efficiency and safety of ademetionine in the correction of liver function in patients with steatohepatitis. The results of an open comparative post-marketing study]. Hastroenterolohiia Gastroenterology, 52 (2), 27-34 [in Russian].

6. Keenan, O.J., Turner, P.G., Yeates, D., \& Goldacre, M.J. (2014). Epidemiology of hospitalized osteochondritis dissecans in young people: incidence, geographical variation and trends over time in England from 2002 to 2010. Knee, 21 (2), 497-500.
7. Marchenko, O.K., Manzhulovskij, V.N., \& Deshovij, Ye.G. (2013). Kompleksnaya fizicheskaya reabilitatsiya pri osteokhondroze grudnogo otdela pozvonochnika s narusheniyem osanki [Complex physical rehabilitation for osteochondrosis of the thoracic spine with impaired posture]. Sportivna meditsina - Sports Medicine, 2, 123-126 [in Russian].

8. European Association for the Study of the Liver (EASL), European Association for the Study of Diabetes (EASD) and European Association for the Study of Obesity (EASO) EASL-EASD-EASO (2016). Clinical Practice Guidelines for the management of non-alcoholic fatty liver disease. J. Hepatol., 64, 1388-1402.

9. WHO: Global Database on Body Mass Index. Retrieved from: http://apps.who.int/bmi/index.jsp?introPage= intro_3.html.

10. WHO (2011). World Health Organization, Global Recommendations on Physical Activity for Health. Retrieved from: http://whqlibdoc.who.int/publications/2010/ 9789241599979_eng.pdf.

\section{ВЛИЯНИЕ НАРУШЕНИЯ МАССЫ ТЕЛА НА ВЫРАЖЕННОСТЬ ПРОЯВЛЕНИЙ ОТЕОХОНДРОЗА У БОЛЬНЫХ НЕАЛКОГОЛЬНОЙ БОЛЕЗНЬЮ ПЕЧЕНИ}

\section{๑я. Ф. Филак, Е. С. Сирчак}

\section{ГВУз «Ужгородский национальный университет»}

РЕзЮМЕ. Остеохондроз (ОХ) позвоночника - одна из наиболее распространенных болезней среди взрослого населения. Среди основных причин развития остеохондроза врачи выделяют нарушения обмена веществ, низкое физическое развитие, генетическую предрасположенность, ожирение, курение.

Цель - изучить клинические особенности течения ОХ поясничного отдела позвоночника (ПОП) у больных неалкогольной жировой болезнью печени (НАЖБП) в зависимости от выраженности нарушения индекса массы тела (ИМТ).

Материал и методы. Под нашим наблюдением находились 42 больных НАЖБП и ОХ ПОП. Всем обследованным пациентам проведены общеклинические, антропометрические, инструментальные и лабораторные исследования. Для исследования двигательной функции позвоночника проводили функциональную оценку подвижности позвоночника, мышечной силы спины и брюшного пресса.

Результаты. У подавляющего большинства обследованных нами пациентов с НАЖБП и ОХ ПОП при анализе результатов антропометрического исследования выявлена избыточная масса тела или ожирение различной степени выраженности. У больных НАЖБП и ОХ ПОП чаще диагностированы избыточный вес (42,9 \%) и ожирение I ст. (28,6 \%) и только у 9,5 \% обследованных установлена нормальная масса тела. Полученные результаты исследования указывают на значительное ухудшение подвижности позвоночника в поясничном отделе у больных НАЖБП и ОХ ПОП. Установлена закономерность прогрессирования показателей двигательной активности в зависимости от выраженности нарушения ИМТ. Максимальные двигательные нарушения определены у пациентов с ожирением II ст. по результатам теста Шобера, теста «пальцы - пол» и разгибания $(2,00 \pm 0,18$ см - p<0,01; $16,71 \pm 0,32 \mathrm{~cm}-p<0,01 ; 7,12 \pm 0,13 \mathrm{~cm}-p<0,05$ соответственно). Эти изменения носят стадийный характер - с минимальными показателями у пациентов с нормальной массой тела и с максимальными при ожирении II ст.

Выводы. У больных НАЖБП и ОХ ПОП при увеличении ИМТ выявлено прогрессирование нарушений двигательной активности поясничного отдела позвоночника. У больных НАЖБП и ОХ ПОП ожирение различной степени выраженности и избыточный вес тела чаще встречается у лиц без образования или со средним специальным образованием.

КЛючЕВЫЕ СЛОВА: неалкогольная жировая болезнь печени; остеохондроз; ожирение. 

MANIFESTATIONS IN PATIENTS WITH NON-ALCOHOLIC FATTY LIVER DISEASE

\section{Uzhhorod National University}

SUMMERY. Osteochondrosis $(\mathrm{OCH})$ of the spine is one of the most common diseases among the adult population. Among the main causes of $\mathrm{OCH}$, doctors identify metabolic disorders, low physical development, genetic predisposition, obesity, smoking.

The aim of the study - to determine the clinical features of the course of OCH of the lumbar spine (LS) in patients with nonalcoholic fatty liver disease (NAFLD) depending on the severity of the violation of body mass index (BMI) in these patients.

Materials and Methods. 46 patients with NAFLD and $\mathrm{OCH}$ were examined. All examined patients underwent general clinical studies. Lumbar spine osteochondrosis was diagnosed based on physical and general clinical methods, as well as the results of computed tomography of the lumbar spine.

Results and Discussion. During examination and analysis of the anthropometric study results in the vast majority of patients with nonalcoholic fatty liver disease (NAFLD) overweight or obesity of varying degrees, manifested by an increase in BMI and waist/thigh index were found. In patients with NAFLD and OCH of LS more often were diagnosed the overweight (42.9\%) and obesity of the first degree (28.6\%) and only $9.5 \%$ of those surveyed had a normal body weight. There were also significant deterioration of mobility (flexibility) of the spine in the lumbar region during its flexion, extension and tilting to the right and left in patients with NAFLD and osteochondrosis of the lumbar spine. At the same time, the regularity of progression of motor activity indicators depending on progression of BMI disturbance was established. Maximum motor disorders were determined in patients with obesity of the second degree according to the results of the Schober test, the test "fingers-floor" and extension $(2.00 \pm 0.18) \mathrm{cm}-\mathrm{p}<0.01 ;(16.71 \pm 0.32) \mathrm{cm}-\mathrm{p}<0.01$; $7.12 \pm 0,13 \mathrm{~cm}-p<0.05$, respectively). These changes are staged - with minimal rates in patients with normal body weight and maximum in patient with obesity of the second degree.

Conclusions. In patients with NAFLD and OCH of LS with increasing BMI revealed the progression of disorders of motor activity of the lumbar spine. In patients with NAFLD and OCH of LS, obesity of severity degree and overweight are more common in people without education or with secondary special education.

KEY WORDS: nonalcoholic fatty liver disease; osteochondrosis; obesity. 